\title{
THE RADIATING MOUSING TECHNIQUE OF THE STRIPED SKUNK
}

SERGE LARIVIÈRE, Department of Biology, University of Saskatchewan, 112 Science Place, Saskatoon, SK. S7N 5E2.

(Send correspondence to: Serge Larivière, Département de Biologie, Pavillon Vachon, Université Laval, Ste-Foy (Quebec), Canada G1K 7P4

The striped skunk is a mammal well known for its conspicuous black and white coloration and powerful chemical defense system. In Saskatchewan, the Striped Skunk(Mephitis mephitis) is also known for inhabiting farm buildings, and raiding the nests of local ducks., ${ }^{1,2,3}$ Although duck eggs are frequently part of the skunk's menu during the waterfowl nesting season, the largest part of the diet of a skunk comes from insects and small mammals such as voles and mice $^{4}$.

Very little is known about the hunting behaviour of Striped Skunks. Unlike weasels, Striped Skunks do not possess the long tubular morphology necessary to access rodent burrows, and lack the ability to perform aerial jumps that the Red Fox exploits in catching small mammals. During an intensive study of the ecology of Striped Skunks around Redberry Lake, Saskatchewan, I had the opportunity to observe, using night-vision equipment, numerous Striped Skunks foraging under the cover of darkness. Other than the main goals of the study 5 , one of the most interesting behaviour observed was the radiating mousing technique of Striped Skunks. One instance in particular stands out in my mind.

At $18: 30$ on July 28,1993 , I located "Pépé", a healthy male whose home range was located $6 \mathrm{~km}$ northwest of Krydor, Saskatchewan. Pépé was

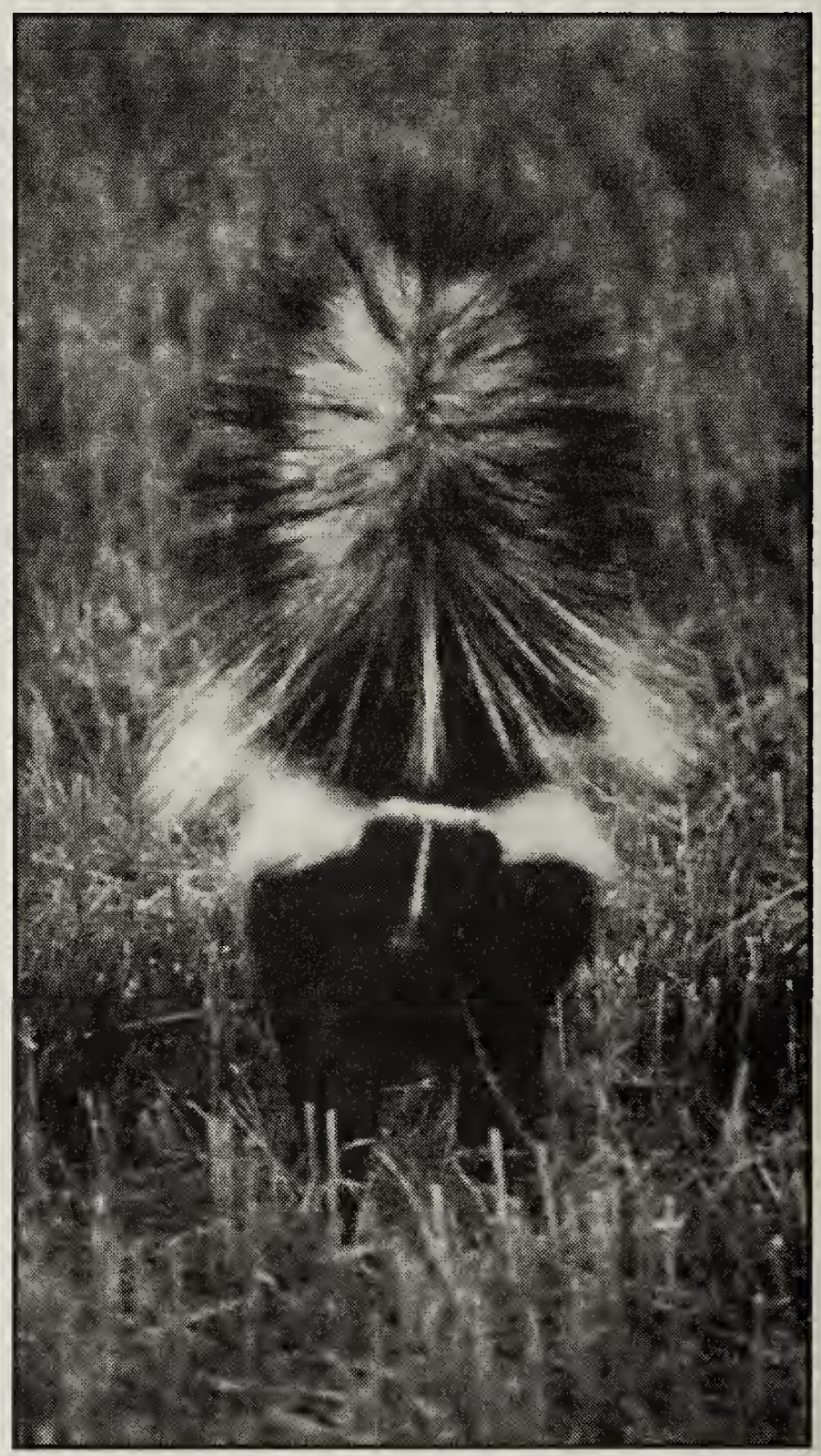

Skunk

Lorne Scott

sleeping above-ground in the tall grass of a wetland of ca. 1 ha in size. Pépé became active around 19:00, and immediately started foraging around the wetland. The sky was clear and I kept the slight breeze in my face to prevent being detected by the skunk. At 20:14, Pépé dug up a small mammal nest (either mice Peromyscus or voles Microtus, hereafter referred to as mice) 
along the wetland periphery. During this first incident, I could see the skunk clearly but I was too far (i.e., $15 \mathrm{~m}$ away) to hear whether mice were caught or not.

At 20:30, I accidentally approached to within $2 \mathrm{~m}$ of the foraging skunk because of the tall wetland grass. As soon as I saw the skunk, I froze. I could hear the skunk "sniffing" intensively for prey in the tall grass. At 20:31, the skunk discovered another active mouse nest $2 \mathrm{~m}$ in front of me. This time, I distinctly heard a number of mice run away from the nest squeaking. Pépé quickly ran down the first mouse and I heard him chewing the mouse as it was squeaking. What followed next is what surprised me. Instead of running around trying to locate more mice, Pépé systematically came back to the nest location, picked up another trail (presumably by smell), and followed it for $1.5 \mathrm{~m}$ until the mouse that made the scent trail was captured. Capture was easily recognized by the sudden sounds of the squeaking mouse and the chewing noises of the skunk, accompanied by the sound of small bones breaking and the termination of the squeaking. Pépé once again came back to the nest, picked up another scent trail, followed it, and caught a third mouse, this time $2 \mathrm{~m}$ from the nest. Then, it came back to the nest, sniffed around, and resumed foraging in a zig-zag pattern along the wetland. The whole incident lasted from 20:31 to $20: 39$, and resulted in the capture and consumption of at least 3 mice.

At 20:56, another mouse nest was discovered and the same scenario was repeated. This time, a minimum of two mice were captured by the skunk using this "radiating" mousing technique. The second incident lasted 3 minutes total, after which the skunk resumed foraging in the wetland.

At 21:05, a third mouse nest was discovered but I was further away this time and could not see or hear clearly whether mice were captured. Pépé became inactive above-ground in a canola field at 21:15.

In the prairies and elsewhere, Striped Skunks spend a large proportion of time foraging along wetlands. ${ }^{5,6}$ In such habitat, the vegetation is usually tall and dense, and hunting by vision is very limited. Furthermore, striped skunks have poor visual abilities, but excellent sense of smell and hearing. ${ }^{7,8}$ Thus, the smell of an undisturbed nest may be strong enough to be detected by a foraging skunk, especially if small mammals are the primary prey and skunks develop olfactory search images. ${ }^{8}$ Furthermore, by being active at night when prey are also most active, striped skunks enhance their chances of encounter with moving prey, which are then more likely to be detected by audition and olfaction. ${ }^{9}$

Striped Skunks concentrate their activities where prey are abundant. In the parklands of Saskatchewan, wetlands and abandoned farmsteads are the two habitats preferred by Striped Skunks because of the high abundance of insects and small mammals, and also because they may provide skunks with other occasional food items such as amphibians, reptiles, and bird nests. Nonetheless, tall vegetation is the norm in these habitats and Striped Skunks must rely on olfaction rather than vision to locate prey. This radiating mousing technique illustrates how the Striped Skunk, a generalist predator, can use its olfaction for capturing small mammals. Striped Skunks may not be specialized mousers like the Red Fox or weasels, nonetheless, they too have figured out an efficient way to cash in on the abundant food source that small mammals constitute. 
1. LARIVIERE, S., and F. MESSIER. 1998. Denning ecology of the striped skunk in the Canadian prairies: implications for waterfowl nest predation. J. Appl. Ecol. 35:207-213.

2. PASITSCHNIAK-ARTS, M., and F. MESSIER. 1995. Risk of predation on waterfowl nests in the Canadian prairies: effects of habitat edges and agricultural practices. Oikos 73:347-355.

3. LARIVIERE, S., and F. MESSIER. 1999. Effects of density and nearest neighbours on the survival of waterfowl nests: can predators recognize high-density patches? Oikos 83:12-20.

4. WADE-SMITH, J., and B.J. VERTS. 1982. Mephitis mephitis. Mamm. Species 173:1-7.

5. LARIVIERE, S. 1998. Space-use patterns of the striped skunk in the Canadian prairies: implications for waterfowl nest predation. Ph.D. dissertation, University of Saskatchewan, Saskatoon.

6. CRABTREE, R.L., L.S. BROOME, and M.L. WOLFE. 1989. Effects of habitat characteristics on gadwall nest predation and nest-site selection. J. Wildl. Manage. 53:129-137.

7. LANGLEY, W.M. 1979. Preference of the striped skunks and opossum for auditory over visual prey stimuli. Carnivore 2:31-34.

8. NAMS, V.O. 1991. Olfactory search images in striped skunks. Behaviour 119:267-284.

9. LARIVIERE, S., and F. MESSIER. 1997. Seasonal and daily activity patterns of the striped skunk (Mephitis mephitis) in the Canadian prairies. J. Zool. London 243:255-262.

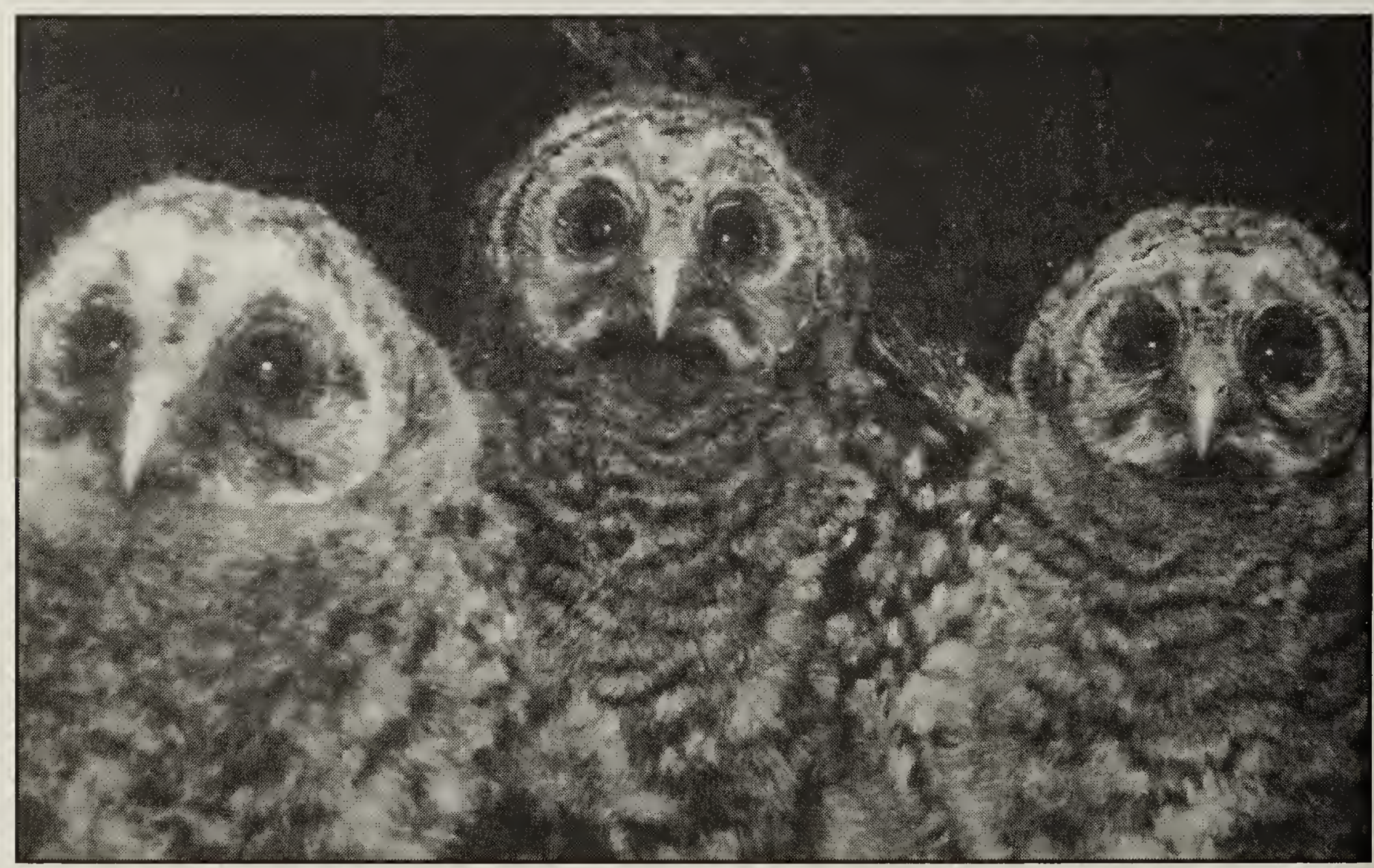

